\title{
REHABILITATED RED FOXES AND COYOTES
}

TERRY and RANDY LANGELIER, Box 306, Blumenort, Manitoba. ROA OCO

As members of the Manitoba Wildlife Rehabilitation Organization (MWRO), we have rehabilitated orphaned Red Foxes and Coyotes for release into the wild during the fall, for the last couple of years. We receive the animals after they have been weaned from the bottle and have been started on solid food by other MWRO members who specialize in infant fox and Coyote care. The releases are termed "slow," because the animals have the doors to their runs left open, and may leave at will. Food (dead rats, mice and rabbits) is left out on a continuing basis, and is slowly cut off in late fall to encourage hunting. Foxes are released at least a month earlier than Coyotes; final shots for rabies, distemper, and mange hopefully give them a slight advantage over their wild counterparts.

Our property east of Steinbach is completely surrounded by poplar bush. Land use in the area is mixed farming. There are more hay fields and pastures intermingled with bush than there are open fields with grain. This benefits our slow release program since there is habitat to support these kinds of animals, which move out and establish territories of their own. Fortunately, our 5-acre yard is well treed, and the runs for the foxes and Coyotes are far enough apart that they cannot see each other, although they can probably detect each other's scent. In 1992, we

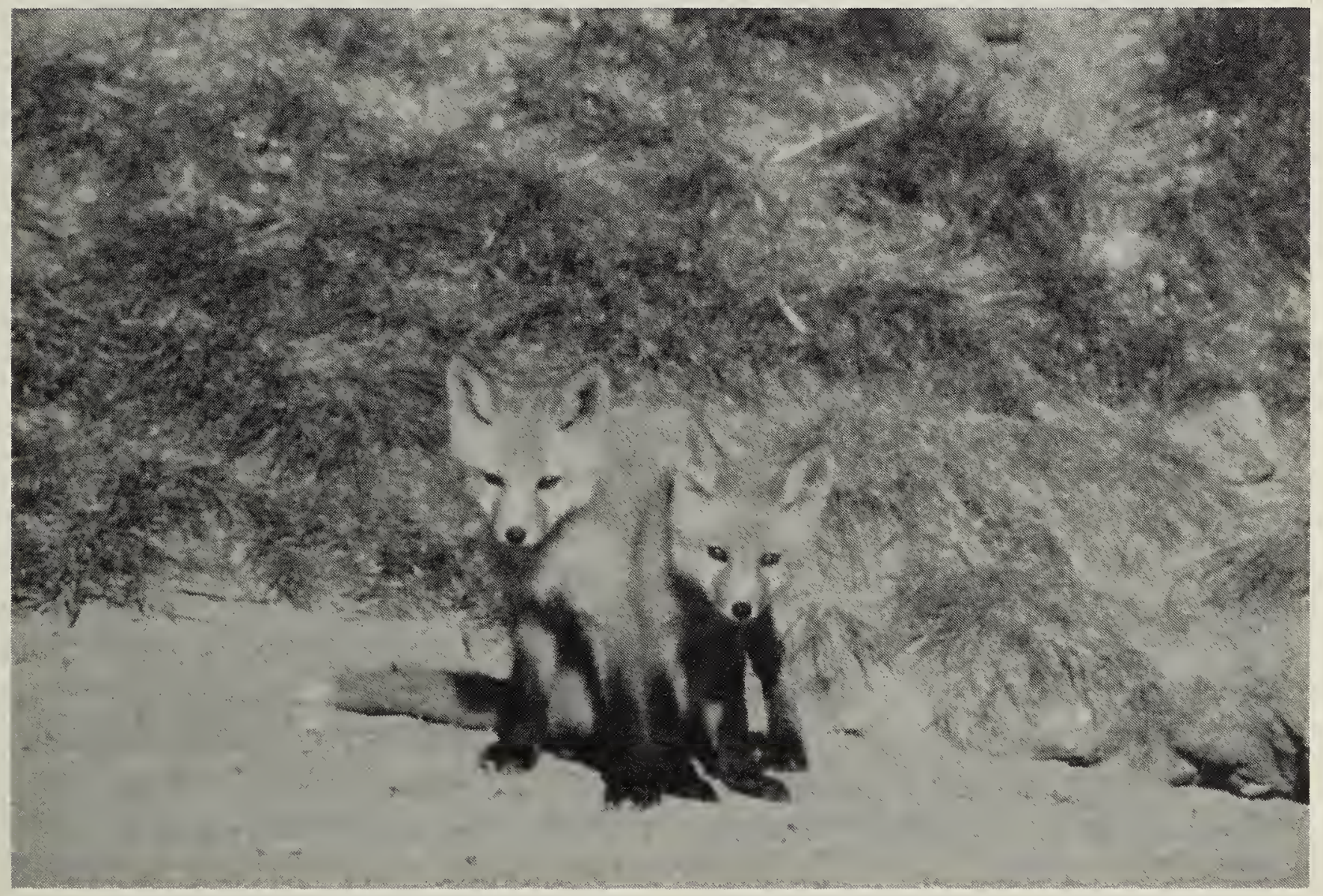




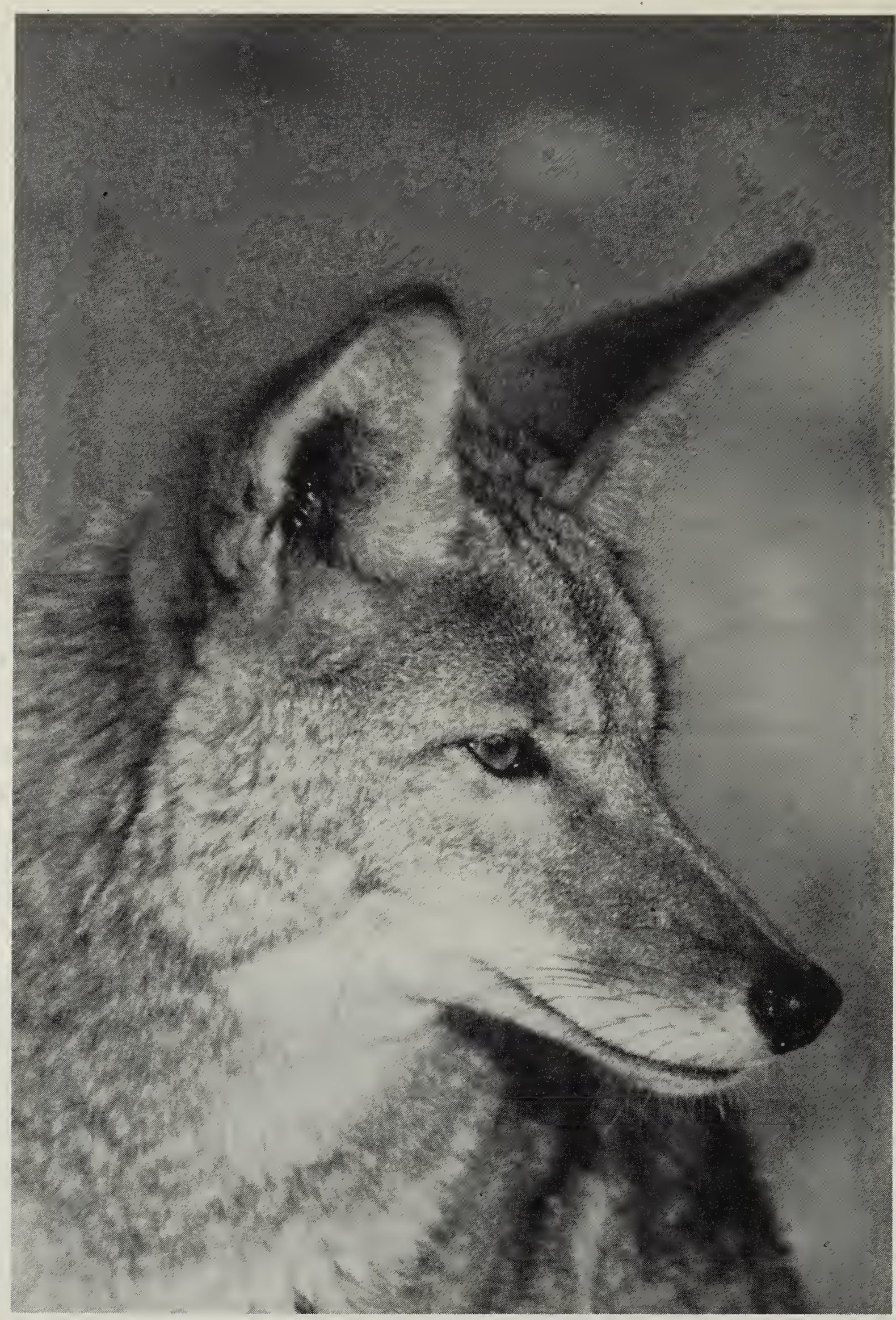

released seven foxes, and in early September 1993 we released 11 uneventfully.

The release of the Coyotes occurs in October. We had two animals from different localities in Manitoba come to us in late spring. They were a male and female of similar age. They remained with us through the sum- mer, and had their diet switched over to mainly mice, rabbits, rats, and whatever road-kills we could obtain that they might naturally encounter as prey in the wild, including small birds, ground squirrels, and deer. We had been advised that the male, the more aggressive of the two, would probably run off as soon as he was allowed, not to be seen again, and 
that the female would likely hang around for a while. Just prior to release, the female hurt her leg. We decided to release the male anyway to give him time to adapt to the surroundings before permanent snowfall. When he stuck around and would not leave the female, we suspected that being social animals they had bonded. Once she stopped limping, the female remained in the run, not attempting to leave, even though the male went in and out to visit her at will. This lasted for four days, but eventually she departed.

At this point, we got a call from our nearest neighbours, asking if we had released some wolves this year. This was not surprising, since the animals were developing their thick winter coats, and these people had never seen Coyotes in their yard before. Unfortunately, having not been raised in a proper family group, these Coyotes seemed to have no fear of buildings, although they did have a healthy fear of people; you could watch them from inside the house, but not approach them. We observed them together on a couple of occasions, but then the female disappeared. There is a wild population of Coyotes in our area, and we wondered how they might have interacted with her.

Meanwhile, the male hung around. We started putting dead animals out for him on a less regular basis, hoping to force him abroad in search of food. He staked out our bird feeder, which had a variety of birds visiting it. There. were Common Redpolls, Blue Jays, Black-capped Chickadees, Pine Grosbeaks, and White-breasted Nuthatches in regular attendance. On 23 October, in broad daylight at about 10:00 a.m., we observed the male Coyote grab a nuthatch from the side of a poplar trunk; he then trotted off and crunched it up, leaving some wing feathers and the head. The Coyote was unbelievably quick about the snatch. The birds were usually pretty wary of him, so it was quite surprising. The next time I observed him hunting was in early December; he was after mice or voles under a few inches of snow, near the trees. He looked robust and quite healthy but shortly thereafter he left us. We have not seen him since. We suspect that the local Coyotes finally ran him off, since their howling chorus had been getting closer to the yard during those nights.

Rare birds: Of the 9,600-odd species of birds on Earth, 1,400 are listed as endangered. The rarest bird in the world is perhaps the Echo parakeet of Mauritius; one breeding pair was reported in 1993. (Several rarer species are known from single sightings, writes author Russell Ash, but must be assumed to be extinct in the absence of records of breeding pairs.) Bird-watching. The Globe and Mail, 8 March 1994. 